"Refugees Issues: Current Status and Directions for the Future", Refugee Policy Group, Washington, D.C., 1983.

In the short compass of 36 pages, this booklet provides an excellent comprehensive summary of most of the key refugee policy and program issues. There are four sections dealing with the initial crisis period, permanent solutions, resettlement and domestic assistance issues in the U.S. and problems of definition.

Of the four, the last is the only flawed section. An initial error is trivial: the Roman numeral VI is used when IV was intended. A second error, however, involves faulty logic. Just because "repressive regimes use economic policies as a means of persecution leaving individuals with political and economic motives for leaving", it does not follow that the presence of those economic motives makes it difficult to ascertain whether individuals were persecuted. As long as people are persecuted, by whatever means, and as long as individuals have a legitimate fear of persecution, whatever other reasons they may have for wanting to stay abroad, they qualify as UN refugees.

The real issue is not the dilemma of sorting out economic versus political motives, but the narrowness of the definition. The Tokyo Symposium on Fundamental Rights of Refugees recommended extending the definition to include victims of external aggression, occupation, foreign domination or serious disturbances of public order. Further, the definition would appy to people who leave their place of habitual residence though not necessarily their country. The Refugee Policy Group appears to endorse such an extension. However, (in a quest for balance) they raise criticisms of those who regard refugees from the perspective of real politick rather than principle. The matter may be resolved by a classification of types of refugees rather than the use of a univocal definition.

They do raise one matter dear to my heart - the proposal to develop a refugee thermometer to weigh different factors so as to designate which refugees should have priority. Other approaches of a more political nature tend to analyze why different countries designate some groups as refugees and

\section{Refugee Issues}

not others. Or they examine the role of the UNHCR in various countries in helping determine refugee status, the level of adherence of various nations to the UNHCR definition, the particular impact of U.S. policy on refugees and the factors to be applied in the determination of refugee status.

As the report points out in Section One, part of the difficulty of definition is the myriad of causes and circumstances which produce refugees - actions of regimes against specific groups or against the whole populace through overt political means or indirectly through economic policies, inhumanitarian international policies, such as those of the U.S. in Central America or the U.S.S.R. in Afghanistan, which push out refugees, and international humanitarian policies which have the effect of pulling them out.

What is needed, as reported in many publications, is an Early Warning System. In a few brief paragraphs, the report reviews the benefits as well as the pitfalls of such a system (i.e., duplication of existing capacities and a confirmation of the obvious). And yet, without the system, there is virtually no planning or coordination.

Who would operate this Early Warning System? The UNHCR treads a delicate diplomatic tightrope. A special UN office, as suggested by Sadruddin Aga Khan, would be suspected by the West of encouraging a further unnecessary increase in the international bureaucracy. It would be suspected by the East of being a UN mandate to interfere in domestic human rights issues. The voluntary agencies have hands-on experience but little training in, or inclination to, objective analytic reporting. Independent research institutes have strong analytic skills but are lacking in operational experience.

Should such an organization be strictly analytical, utilize public relations or even engage in advocacy? The latter three roles would require delicacy. The organization would not want to be accused of inducing refugees to flee.

Should a special UN office for humanitarian affairs be instituted to help prevent mass asylum flows or should the world order simply accept them as a fact of life and come to an agreement on how to protect the refugees?

How are refugees to be better protected? How are claimants to be both quickly and fairly adjudicated? These and other issues such as detention centres and temporary refugee status are weighed.

In the section on permanent solutions, it is clear that the Refugee Policy Group is interested in linking development aid to settlement in Third World countries. They are fully aware of the shortcomings of such a policy (i.e., although repatriation may be the best solution it is also the least likely). And resettlement is regarded as becoming increasingly difficult.

The section on resettlement and domestic assistance suffers from its U.S. focus. There is much discussion of the conflict between the divided authority of the State Department and Health and Human Services (HHS). The analysis of the role of voluntary agencies is too sketchy and the outline of alternatives to the current system of channelling aid to refugees is too detached. The operational issues are so well worn that they seem trite in the context of the report.

Whatever its shortcomings, this brief but packed booklet is an essentiai reference for those involved in refugee issues.

H.A.

\section{Books Received}

The World's Refugees: A Test of Humanity. By Gil Loescher with Ann Dull Loescher. An account of the history and current status of the world's refugees. Illustrated with photographs and maps. Harcourt Brace Jovanovich, 1250 Sixth Avenue, San Diego, California, 92101.

\section{***}

The Global Refugee Problem: U.S. and World Response. THE ANNALS of the American Academy of Political and Social Science. Volume 467. May 1983. Special editors, Gilburt D. Loescher and John A. Scanlan. \$7.95 (clothbound, \$15.00) prepaid. THE ANNALS, c/o Sage Publications, Inc., 275 South Beverly Drive, Beverly Hills, California, 90212. 